\title{
REE PATTERNS FOR APATITES FROM PROTEROZOIC PHOSPHATIC METASEDIMENTS, FINLAND
}

\author{
PENTTI REHTIJÄRVI
}

\begin{abstract}
REHTIJÄRVI, PENTTI, 1983: REE patterns for apatites from Proterozoic phosphatic metasediments, Finland. Bull. Geol. Soc. Finland 55, 1, 77-82.

Several occurrences of uranium- and apatite-bearing metasediments are known in the Precambrian of Finland. The characteristic rock types in the occurrences: metaphosphorite, apatite-bearing carbonate and calc-silicate rocks and apatite-quartz-feldspar gneiss have been interpreted as metamorphic derivatives of phosphorite and phosphatic sedimentary and pyroclastic rocks. Present modes of occurrence of uranium include incorporation into fluorapatite and into evenly disseminated uraninite crystals. Thirteen fluorapatite concentrates extracted from these metasediments were analysed for $\mathrm{REE}, \mathrm{U}$ and Th by instrumental neutron activation. The concentrates averaged 113 ppm La, 118 ppm Ce, 21 ppm Sm, 4.8 ppm Eu, 13.7 ppm $\mathrm{Yb}, 485 \mathrm{ppm} \mathrm{U}$ and $2.0 \mathrm{ppm}$ Th. The REE distribution patterns of the concentrates are reasonably similar and resemble the REE pattern of the apatite from the Tertiary Florida phosphate rock. A marine environment of deposition is suggested for the original phosphatic material.
\end{abstract}

Key words: REE, U, apatite, metasediment, Proterozoic, Finland.

Pentti Rehtijärvi: Geological Survey of Finland, Kivimiehentie 1, SF-02150 Espoo 15, Finland.

\section{Introduction}

Since 1959, a dozen occurrences of uranium-bearing phosphatic rocks have been discovered in Finland, most of them by the Exploration Department of Outokumpu Oy. On the basis of these phosphatic phases in the Svecokarelian sequence of sedimentary and volcanogenic rocks, a Lower Proterozoic U-P zone (Fig. 1) within the Baltic Shield has been described in a preliminary report by Äikäs (1980).
Characteristic of these occurrences are phosphorite-banded dolomite, apatitebearing carbonate- and calc-silicate rocks, and fine-grained apatite-quartz-feldspar gneiss. These rocks can be interpreted as metamorphic derivatives of phosphatic sediments and pyroclastic material. The metamorphic grade varies from intermediate greenschist to high amphibolite facies. The occurrences have two prominent geochemical features: the $\mathrm{P}_{2} \mathrm{O}_{5} / \mathrm{U}$ ratio varies between 100 and 300 , and the content of tho- 


\section{Pt/A boundary zone}

quartzite areas

albitite zone

U-P zone

IIIIII migmatite zone

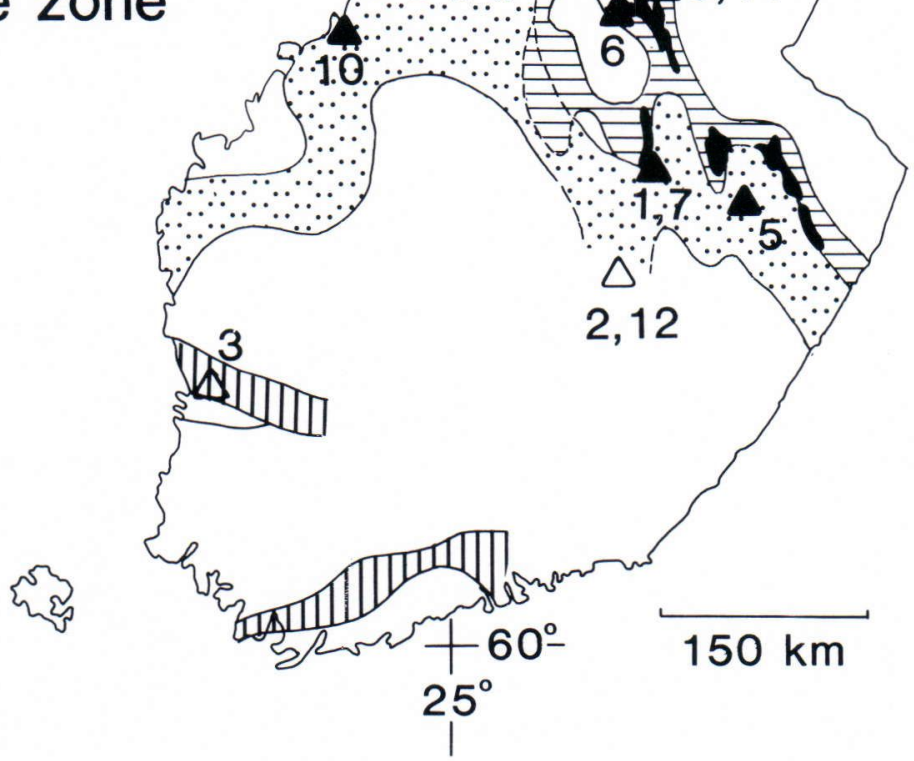

Fig. 1. Zones of various types of uranium occurrences in the Proterozoic of Finland, based on the unpublished map prepared by R. Sarikkola, Outokumpu Oy (Äikäs 1980). Pt/A: Proterozoic/Archean; $\mathrm{U}-\mathrm{P}$ zone: zone of uraniferous phosphatic occurrences. The triangles show the sampling sites and the numbers refer to the samples (see Table 1.) 
rium is low, usually less than $10 \mathrm{ppm}$. The average uranium and phosphorus contents do not exeed $0.04 \%$ uranium and $5 \% \mathrm{P}_{2} \mathrm{O}_{5}$. So far, the occurrences found are too small or of too low a grade to be of economic importance.

Radiometric dates on whole rock samples from the Lampinsaari and Temo occurrences indicate regional metamorphism about 1880 Ma ago (Vaasjoki et al. 1980). An analysis of uranium thucolite from the Nuottijärvi occurrence gives an age of $1897 \mathrm{Ma}$. This suggests that the U-P occurrences were deposited not later than $1900 \mathrm{Ma}$ ago and, judging by a dated banded iron ore occurrences lying in the corresponding stratigraphic unit, not earlier than 2080 million years ago. The observed lead ratios suggest geochemical separation between uranium and thorium before sedimentation.

\section{Mode of occurrence of apatite and uranium}

The phosphate in the U-P rocks occurs as fluorapatite. The apatite is recrystallized and frequently euhedral with a characteristic grain size of $0.01 \mathrm{~mm}$ to $0.1 \mathrm{~mm}$. Larger grains are scarce. Apatite occurs as disseminations, streaks and bands, and as thin meta-phosphorite intercalations and lenses. There is a strong correlation between the contents and distributions of uranium and apatite.

The prevailing mode of occurrence of uranium seems to vary from one rock type to another and from one occurrence to another. The uranium-bearing minerals include apatite, uraninite, sphene, uraniumthucolite, and unidentified black crystallites and U-Ti minerals. When uraninite or uranium-bearing mineral inclusions are present, we may well assume that most of the total uranium is incorporated in these minerals.

The uranium is distributed unevenly.
When uranium-bearing mineral inclusions are scarce or absent, the prevailing mechanism for uranium fixation is probably substitution. Leaching experiments under laboratory conditions showed that 70 to $90 \%$ of the total uranium can be leached with acid ferric sulphate at room temperature within 4 to 7 hours (Soljanto et al. 1979).

\section{Samples and methods}

The contents of uranium, thorium, lanthanum, cerium, samarium, europium, terbium and ytterbium were analysed from 13 apatite concentrates by the instrumental neutron activation method (cf. Rosenberg 1972, Rosenberg et al. 1982). The samples were analysed in the Reactor Laboratory, Technical Research Centre of Finland, Espoo. The sampling sites are shown in Figure 1.

Special attention was paid to errors produced by the high uranium content. The isotopes of lanthanum, cerium, neodymium and samarium analysed are fission products of uranium, and the peaks of neptunium interfere with the peaks of samarium and lutetium. Fission and interference per microgram of uranium were found to increase the results for lanthanum by $0.016 \mu \mathrm{g}$, for cerium by $0.26 \mu \mathrm{g}$, for neodymium by $0.22 \mu \mathrm{g}$ and for samarium by $0.1 \mu \mathrm{g}$.

\section{Results and discussion}

Apatite of marine origin is characterized by a low thorium content and hence by a low Th/U ratio (Altschuler et al. 1958). The mean content of thorium in the samples studied was found to be $2.0 \mathrm{ppm}$ (Table 1). The mean of the uranium contents, 486.5 ppm, shows strong enrichment of uranium in apatite. 
Table 1. The contents of $\mathrm{La}, \mathrm{Ce}, \mathrm{Sm}, \mathrm{Eu}, \mathrm{Tb}, \mathrm{Yb}, \mathrm{U}$ and $\mathrm{Th}(\mathrm{ppm})$ in thirteen apatite concentrates with mean values and standard deviations.

\begin{tabular}{lrrrrrrrr}
\hline & La & Ce & Sm & Eu & Tb & Yb & U & Th \\
\hline 1 & 86 & 116 & 17 & 5.5 & 2.5 & 8.7 & 295 & 1.1 \\
2 & 100 & 184 & 21 & 4.7 & 2.6 & 5.9 & 56 & 2.4 \\
3 & 67 & 85 & 18 & 3.8 & 3.5 & 18.0 & 290 & 0.5 \\
4 & 87 & 25 & 13 & 2.8 & 2.3 & 8.7 & 650 & 0.5 \\
5 & 140 & 139 & 31 & 7.7 & 5.6 & 15.0 & 280 & 2.5 \\
6 & 66 & 118 & 25 & 4.8 & 4.9 & 15.0 & 950 & 3.0 \\
7 & 111 & 80 & 17 & 3.8 & 2.8 & 13.0 & 530 & 0.7 \\
8 & 65 & 59 & 11 & 3.5 & 2.8 & 14.0 & 440 & 4.5 \\
9 & 114 & 148 & 18 & 6.0 & 5.8 & 32.0 & 1200 & 1.7 \\
10 & 110 & 200 & 46 & 5.9 & 5.8 & 17.0 & 144 & - \\
1 & 190 & 121 & 22 & 5.7 & 3.9 & 17.0 & 710 & 2.4 \\
12 & 180 & 200 & 21 & 4.8 & 2.1 & 6.3 & 230 & 2.8 \\
13 & 150 & 53 & 16 & 4.6 & 2.2 & 7.7 & 550 & - \\
\hline Mean & 112.8 & 117.5 & 21.2 & 4.8 & 3.6 & 13.7 & 486.5 & 2.0 \\
Std.dev. & 41.6 & 56.3 & 9.0 & 1.3 & 1.4 & 7.0 & 328.5 & 1.2 \\
\hline
\end{tabular}

1. Nilsiä, Temo

2. Juva, Näärinki

3. Noormarkku, Harjakangas

4. Vihanti, Lapinsaari (DH $1574 / 66.40-67.05 \mathrm{~m})$

5. Polvijärvi, Haapasaari

6. Sotkamo, Kokkomäki

7. Nilsiä, Temo

8. Vihanti, Lampinsaari (DH $1574 / 84.60-85.30 \mathrm{~m}$ )

9. Paltamo, Nuottijärvi

10. Kälviä, Ruotsalo

11. Paltamo, Nuottijärvi

12. Juva, Näärinki

13. Vihanti, Lampinsaari (DH $1574 / 69.50-70.30 \mathrm{~m}$ )

The distribution patterns of rare earth elements in apatite concentrates are reasonably similar (Fig. 2). The observed cerium depletion is not so marked as might be expected from the results obtained from metalliferous sediments of the Troodos massif, Cyprus (Robertson and Fleet 1976). Since the rock association includes felsic metavolcanics, the water-rock interaction may have raised the cerium content locally and changed the environmental conditions. The mineral paragenesis and the order of crystallization of the minerals are also known to affect the distribution pattern (Puchelt and Emmermann 1976). Owing to the anomalous amount of apatite the content of rare earth elements in other mineral phases present can be considered negligible. Concentrates 4 and 13 from Vihanti show marked cerium anomalies. These concentrates were extracted from metaphosphorite intercalations in dolomite host rocks and, therefore, the result confines the existence of cerium depletion to normal marine sedimentation. The coexisting europium depletion indicates either a two-stage enrichment of rare earth elements or the conditions prevailing in the sea water. The europium anomalies may well be due to the crystallization of the phosphate precipitate. Low oxygen fugacities are indicated by coexisting and probably syngenetic sulphides.

The apparent resemblance between the distribution pattern of rare earth elements in 


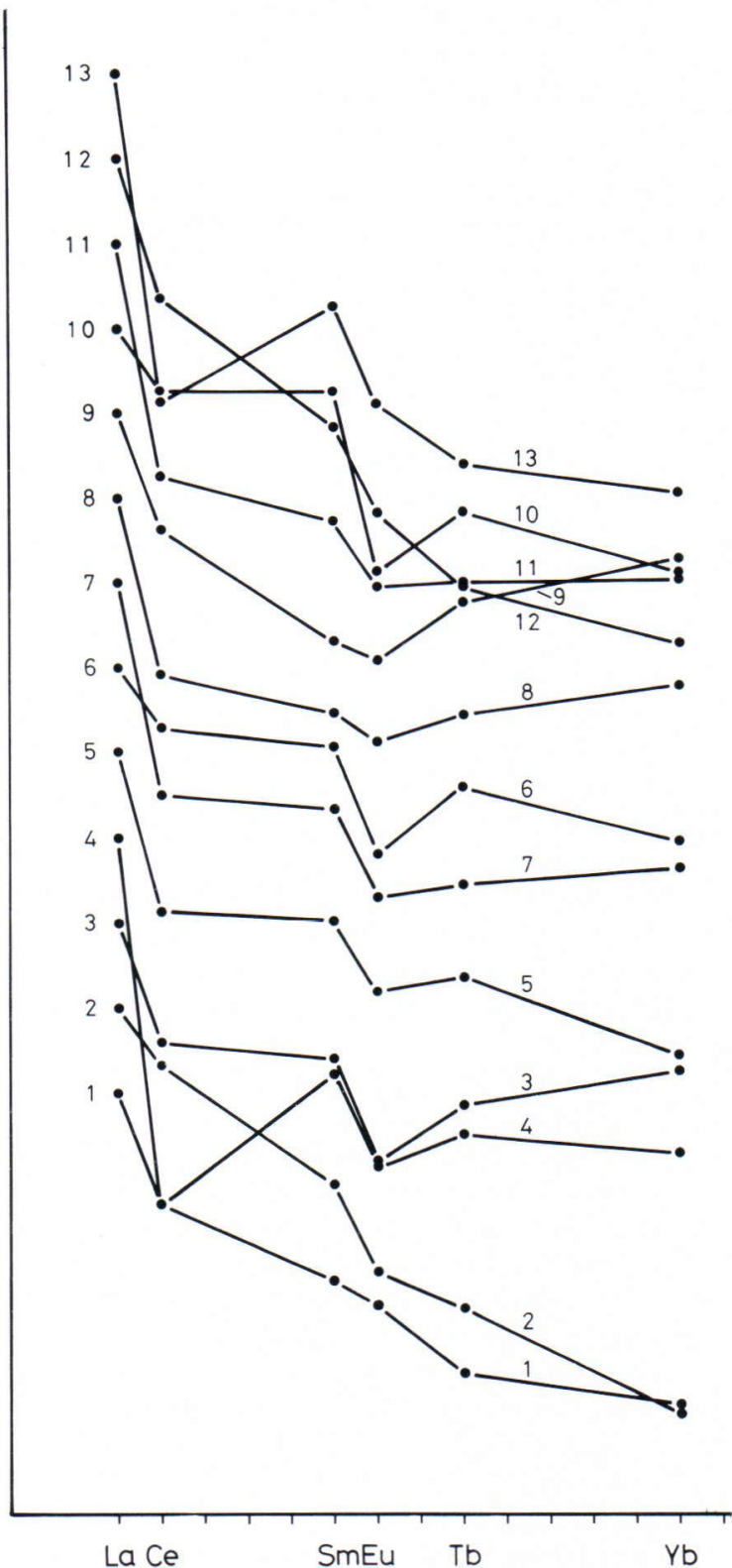

Fig. 2. Chondrite-normalized REE distribution patterns for uranium-bearing apatites. For the numbers see Table 1 .

phosphorite from the Bone Valley Formation of Florida, present-day ocean water and the mean of the rare earth contents in the apatite concentrates (Fig. 3) indicates similarities in the geologic environment of deposition (cf. Graf 1978). Recent marine phosphatic sediments and phosphorites have been shown to occur in warm latitudes between $40^{\circ} \mathrm{N}$ and $40^{\circ} \mathrm{S}$ (Sheldon 1964). The precipitation of apatite has largely been attributed to upwelling of deep ocean water. Sheldon (1964) has also shown that the paleolatitudinal distribution of ancient phosphorites is similar to the latitudinal distribution of younger phosphorites. According to paleomagnetic studies, the paleolatitude of Finland during the deposition of the phosphatic sediments and volcanics was 20 to 25 degrees (Pesonen and Neuvonen 1981).

Froelich et al. (1977) have found that phosphorus is deposited about 20 times faster in metalliferous sediments near the crest of the East Pacific Rise than on the adjacent flank deposits and about 40 times faster on the crest than in the Bauer Deep. Consequently, submarine hydrothermal vents in any tectonic setting are likely to produce anomalous phosphate deposition, as at Vihanti, Finland, for instance, where apatite-

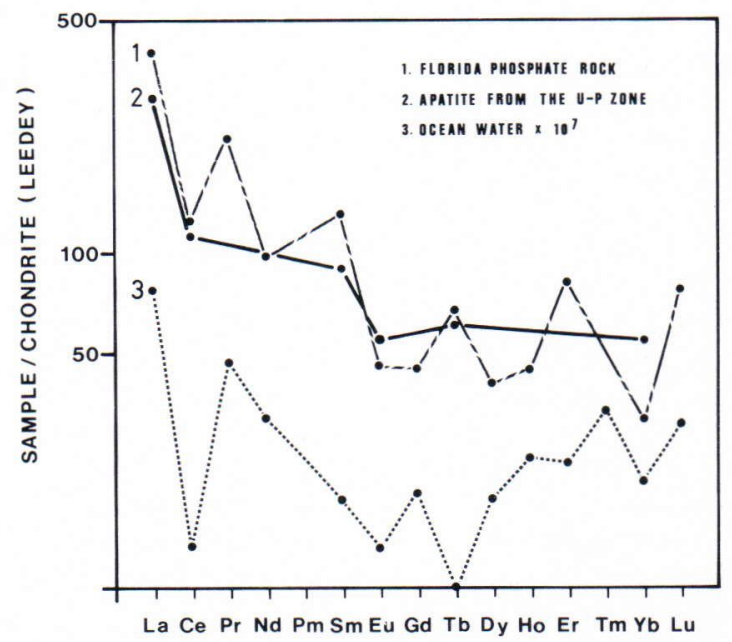

Fig. 3. Comparison between the chondritenormalized REE contents in the Florida phosphate rocks (Altschuler et al. 1967), in the mean apatite concentrate (this study) from the U-P zone and in the present-day ocean water (Goldberg et al. 1963). 
bearing rocks and stratiform sulphide ores seem to have a close stratigraphic relationship (Rehtijärvi et al. 1979).

The results of the present study indicate that regional metamorphism does not essentially affect the primordial composition of rare earth elements in apatite. Hence, their distribution pattern might be used for deducing the environment of their deposition elsewhere in metamorphic terrains, and perhaps for geochemical exploration for stratabound massive sulphides as well.

Acknowledgments. The manuscript has profited from the comments of Mr. Olli Äikäs who is also due to the many discussions on the subject. The concentrates were extracted by Mr. Juha Rontu. Mrs. Gillian Häkli corrected the English of the manuscript.

\section{References}

Äikäs O., 1980. Uraniferous phosphorite and apatite-bearing gneisses in the Proterozoic of Finland. "Uranium in the Pine Creek Geosyncline», 675-681, IAEA, Vienna.

Altschuler Z. S., R. S. Clarke \& E. J. Young, 1958. Geochemistry of uranium in apatite and phosphorite. U.S. Geol. Surv. Prof. Paper 314-D, 90 p.

Altschuler Z. S., S. Berman \& F. Cuttitta, 1967. Rare earths in phosphorites - geochemistry and potential recovery. U.S. Geol. Surv. Prof. Paper 575-B, 1-9.

Froelich P. N., M. L. Bender \& G. R. Heath, 1977. Phosphorus accumulation rates in metalliferous sediments on the East Pacific Rise. Earth Planet. Sci. Lett. 34, 351-359.

Goldberg E. D., M. Koide, R. A. Schmitt \& R. H. Smith, 1963. Rare-earth distributions in the marine environment. Jour. Geophys. Res. 68, $4209-4217$.

Graf J. L., Jr., 1978. Rare earth elements, iron formations and sea water. Geochim. Cosmochim. Acta 42, 1845-1850.

Pesonen L. J. \& K. J. Neuvonen, 1981. Palaeomagnetism of the Baltic Shield - Implications for Precambrian tectonics, 623-648, in Precambrian plate tectonics, ed. A. Kröner. Elsevier, Amsterdam 781 p.

Puchelt H. \& R. Emmermann, 1976. Bearing of rare earth patterns of apatites from igneous and metamorphic rocks. Earth Planet. Sci. Lett. 31, 279-286.
Rehtijärvi P., O. Äikäs \& M. Mäkelä, 1979. A Middle Precambrian uranium- and apatite bearing horizon associated with the Vihanti zinc ore deposit, western Finland. Econ. Geol. $74,1102-1117$.

Robertson A. J. F. \& A. J. Fleet, 1976. The origin of rare earths in metalliferous sediments of the Troodos Massif, Cyprus. Earth Planet. Sci. Lett. 28, 385-394.

Rosenberg $R$. J., 1972. Instrumental activation analysis of lunar samples. Suomen Kemistilehti B 45, 399-404.

Rosenberg R. J., M. Kaistila \& R. Zilliacus, 1982. Instrumental epithermal neutron activation analysis of solid geochemical samples. Jour. Radioanal. Chem. 71, 419-428.

Sheldon, R. P., 1964. Paleolatitudinal and paleogeographic distribution of phosphorite. U. S. Geol. Surv. Prof. Paper 501-C, C106-C113.

Soljanto P., P. Rehtijärvi \& O. H. Tuovinen, 1979. Uraanin erotus kvartsiiteista ja fosfaattisista metasedimenteista bakteeriliuotuksen avulla, Helsingin yliopiston Mikrobiologian laitoksen julkaisuja 18/1979.

Vaasjoki M., O. Äikäs \& P. Rehtijärvi, 1980. The age of mid-Proterozoic phosphatic metasediments in Finland as indicated by radiometric U-Pb dates. Lithos 13, 257-262.

Manuscript received, February 15, 1983 